\title{
Single-use Albarran module: A removable elevator system to enhance safety in biliary endoscopy?
}

\section{다 (1) $\odot$}

\author{
Authors \\ Clara Benedetta Conti, Roberto Frego, Alessandro Ettore Redaelli, Marta Maino, Giacomo Mulinacci, Marco Emilio \\ Dinelli
}

Institution

Interventional Endoscopy - ASST Monza, Ospedale San

Gerardo, Monza, Italy

submitted 4.6.2021

accepted after revision 24.8.2021

Bibliography

Endosc Int Open 2021; 09: E1914-E1916

DOI 10.1055/a-1629-1221

ISSN 2364-3722

(C) 2021. The Author(s).

\begin{abstract}
This is an open access article published by Thieme under the terms of the Creative Commons Attribution-NonDerivative-NonCommercial License, permitting copying and reproduction so long as the original work is given appropriate credit. Contents may not be used for commercial purposes, or adapted, remixed, transformed or built upon. (https://creativecommons.org/licenses/by-nc-nd/4.0/) Georg Thieme Verlag KG, Rüdigerstraße 14, 70469 Stuttgart, Germany
\end{abstract}

Corresponding author

Clara Benedetta Conti, ASST Monza, Via Giambattista

Pergolesi, 33, 20900 Monza MB, Italy

Fax: +00393496009047

benedetta.conti1@gmail.com
Bacterial infections are a major burden in biliary endoscopy. Besides incomplete manual cleaning of endoscopes, hard-toclean components of duodenoscopes are responsible for a substantial rate of bacterial contamination. A large meta-analysis showed that $15 \%$ of duodenoscopes harbored microorganisms of gastrointestinal or oral origin, independent from the colony forming unit (CFU) count. This indicates that the current reprocessing and process control procedures, even with ethylene oxide (ETO), could be insufficient [1]. Therefore, US Food and Drug Administration (FDA) warnings led companies to redesign duodenoscopes with the aim of enhancing safety. Disposable caps or caps + elevator are available options on the market [23]. Moreover, two disposable duodenoscopes models have recently been approved by the FDA: the Boston Scientifc EXALT Model D and the Ambu A/S Ambu aScope Duodeno. Studies on disposable duodenoscope feasibility and possible economic impact on the market yielded interesting results, although the data are still preliminary [4-8].

In this paper, we present an innovative solution of a duodenoscope with a removable cap, wire, and distal lever mechanism. This elevator system is called the single-use Albarran module (Karl Storz) (\Fig. 1). With it, a large, open surface can be created that is easy to brush and clean, as is the case with any other instrument without a bifurcated channel. Basically, the module is assembled and removed before and after every procedure, to be reprocessed separately from the rest of the duodenoscope (even with ETO). Interestingly, the distal end of the duodenoscope belongs to the removable module
( $\triangleright$ Fig.2). This detail makes the cleaning both the channel and the tip easier. Karl Storz conducted some tests on duodenoscopes contaminated with organic fluids, such as blood. After removal of the single-use Albarran module and duodenoscope reprocessing, the instruments achieved the officially required level of cleaning (i. e. $<6.4 \mu \mathrm{g} / \mathrm{cm}^{2}$ for protein, $<2.4 \mu \mathrm{g} / \mathrm{cm}^{2}$ for hemoglobin and $<4 \log _{10} / \mathrm{cm}^{2}$ for bacteria) [9].

Ten endoscopic retrograde cholangiopancreatographies (ERCPs) were performed in nine consecutive patients using the single-use Albarran module. Data are summarized in > Table 1. The setting was urgent in one case and elective in nine. A native papilla was present in seven patients (70\%); the bile duct cannulation and successful procedure rates were both $100 \%$. Mean procedure time was 30 minutes. Indications for ERCP were biliary lithiasis in seven cases and cancer palliation in two cases. Sphincterotomy and balloon dilation were performed in five and four cases, respectively. Mechanical lithotripsy was performed only once, whereas stone clearing required balloon dilation in six cases. Brushing for cytology was done in one case and stenting for palliation in two.

The aim of this small study was to gain insights into this novel device, with special attention directed towards identifying any technical problems related to use of the disposable systems. Notably, we did not find any issues with devices insertion, grip, friction, strength, or width of the elevator movements, in contrast to the study by Bang et al. [10] Because of the type of study (case series) and small sample size, it was not possible to compare the single-use Albarran maneuverability and mechan- 

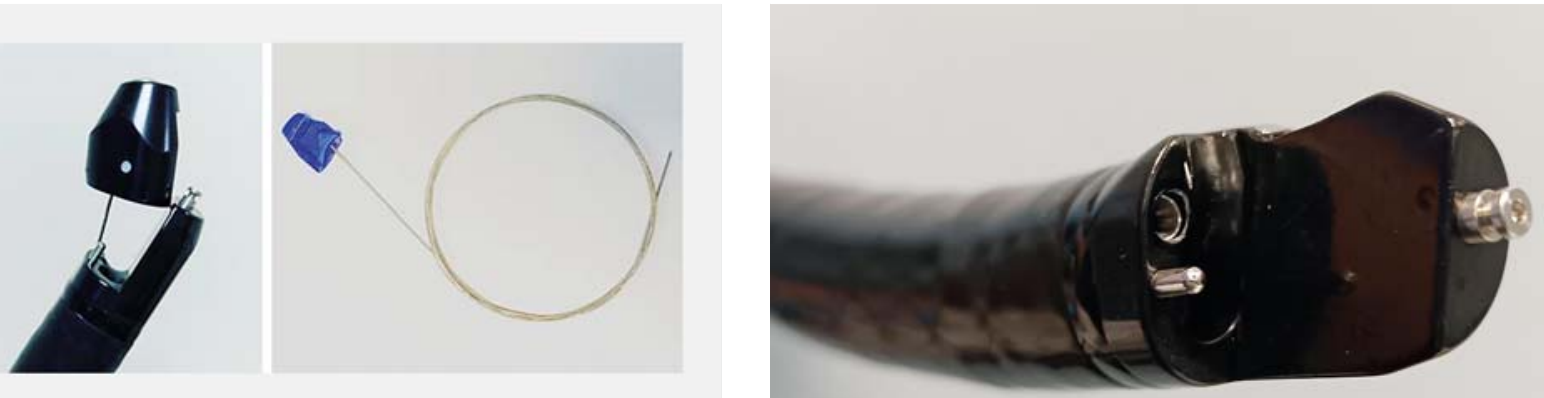

- Fig. 1 The image on the left shows the lever mechanism to remove the cap; the image on the right shows the wire that is inserted in the cap.

Fig. 2 The image shows the distal portion of the endoscope, without wire and cap.

- Table 1 Elevator performance evaluation¹.

\begin{tabular}{|c|c|c|c|c|c|c|c|}
\hline $\begin{array}{l}\text { Patient } \\
\text { (sex; } \\
\text { age) }\end{array}$ & $\begin{array}{l}\text { Indica- } \\
\text { tion }\end{array}$ & $\begin{array}{l}\text { Bile duct } \\
\text { cannulation }\end{array}$ & $\begin{array}{l}\text { Operative } \\
\text { procedure }\end{array}$ & $\begin{array}{l}\text { Operative } \\
\text { device }\end{array}$ & $\begin{array}{l}\text { Stent charac- } \\
\text { teristics }\end{array}$ & $\begin{array}{l}\text { Procedure set- } \\
\text { ting/duration } \\
\text { (min) }\end{array}$ & $\begin{array}{l}\text { Elevator } \\
\text { perform- } \\
\text { ance }\end{array}$ \\
\hline $\mathrm{M}, 83$ & $\begin{array}{l}\text { Biliary } \\
\text { AP }\end{array}$ & Yes & $\begin{array}{l}\text { Precut, plastic } \\
\text { stent placement }\end{array}$ & & $\begin{array}{l}\text { Plastic, } 10 \mathrm{Fr} \text {, } \\
5 \mathrm{~cm}\end{array}$ & Elective/31 & Good \\
\hline M,76 & $\begin{array}{l}\text { CBD } \\
\text { stones }\end{array}$ & $\begin{array}{l}\text { Yes (previous } \\
\text { sphincterot- } \\
\text { omy) }\end{array}$ & $\begin{array}{l}\text { Stent removal, } \\
\text { balloon dilation, } \\
\text { mechanic litho- } \\
\text { tripsy, stent } \\
\text { placement }\end{array}$ & $\begin{array}{l}\text { CRE Boston } \\
\text { Scientific, bal- } \\
\text { loon dilator } \\
12-15 \mathrm{~mm} \text {, Fo- } \\
\text { garty catheters }\end{array}$ & NA & Elective/34 & Good \\
\hline$F, 82$ & $\begin{array}{l}\text { Biliary } \\
\text { hilar } \\
\text { stricture }\end{array}$ & Yes & $\begin{array}{l}\text { Balloon dilation } \\
\text { of main hepatic } \\
\text { ducts }\end{array}$ & $\begin{array}{l}\text { CONMED balloon } \\
\text { dilator } 6.00 \mathrm{~mm}\end{array}$ & NA & Elective/43 & Good \\
\hline$M, 53$ & $\begin{array}{l}\text { Cancer } \\
\text { pallia- } \\
\text { tion }\end{array}$ & Yes & Stent placement & & $\begin{array}{l}\text { Partially cov- } \\
\text { ered SEMS } \\
10 \mathrm{~mm} \emptyset, 6 \mathrm{~cm}\end{array}$ & Elective/19 & Good \\
\hline$M, 59$ & $\begin{array}{l}\text { CBD } \\
\text { stones }\end{array}$ & Yes & $\begin{array}{l}\text { Balloon dilation } \\
\text { CBD clearance }\end{array}$ & $\begin{array}{l}\text { Dormia basket, } \\
\text { CRE Boston } \\
\text { Scientific, bal- } \\
\text { loon dilator } \\
12-15 \mathrm{~mm}\end{array}$ & NA & Elective/20 & Good \\
\hline M,76 & $\begin{array}{l}\text { Biliary } \\
\text { AP }\end{array}$ & Yes & Stent placement & & $\begin{array}{l}\text { Plastic } 10 \mathrm{Fr} \text {, } \\
5 \mathrm{~cm}\end{array}$ & Urgent/43 & Good \\
\hline M;71 & $\begin{array}{l}\text { CBD } \\
\text { stones }\end{array}$ & Yes & CBD clearance & & NA & Elective/22 & Good \\
\hline$F ; 42$ & $\begin{array}{l}\text { Cancer } \\
\text { pallia- } \\
\text { tion }\end{array}$ & Yes & $\begin{array}{l}\text { Balloon dilation } \\
\text { Stent placement }\end{array}$ & $\begin{array}{l}\text { CRE Boston } \\
\text { Scientific, bal- } \\
\text { loon dilator } \\
10-12 \mathrm{~mm}\end{array}$ & $\begin{array}{l}\text { Partially cov- } \\
\text { ered SEMS }\end{array}$ & Elective/30 & Good \\
\hline$F ; 82$ & $2^{\text {nd }}$ look & $\begin{array}{l}\text { Yes (previous } \\
\text { sphincterot- } \\
\text { omy) }\end{array}$ & $\begin{array}{l}\text { Stent removal } \\
\text { Brushing } \\
\text { Stent placement }\end{array}$ & & $\begin{array}{l}2 \text { plastic } \\
\text { stents, } 10 \mathrm{Fr} \text {, } \\
12 \mathrm{~cm}\end{array}$ & Elective/43 & Good \\
\hline M;41 & $2^{\text {nd }}$ look & $\begin{array}{l}\text { Yes (previous } \\
\text { sphincterot- } \\
\text { omy) }\end{array}$ & CBD clearance & & NA & Elective/15 & Good \\
\hline
\end{tabular}

NA, not applicable; AP, acute pancreatitis; CBD, common bile duct; PC, pancreatic cancer; SEMS, self-expandable metallic stent.

1 Special attention was given to ease of accessory insertion, grip, friction, strength, and width of the movement, rated as good = no problems nor difficulties; fair= any problem occurred with no interference with the outcome of the procedure; poor=any problem occurred significant enough to interrupt the procedure or change the elevator. 
ical features with the standard module. The only difference from the standard Albarran module was a shorter width during the elevator stroke, which did not hinder the planned interventions. In our experience, the disposable device allows the use of all devices commonly employed in biliary endoscopy. Importantly, no cases of sepsis or infectious events were reported. Unfortunately, a direct comparison of infectious event rate between the standard and single-use Albarran module is not possible at this time, due to the small sample size in the present case series. However, to our knowledge, this is the first description of single-use Albarran module use during routine endoscopy in real-life settings. Further studies and randomized controlled trials are needed to address comparisons with the standard duodenoscopes and to better evaluate its use in clinical practice.

\section{Competing interests}

The authors declare that they have no conflict of interest.

References

[1] Larsen S, Russell RV, Ockert LK et al. Rate and impact of duodenoscope contamination: A systematic review and meta-analysis. EClinicalMedicine 2020; 25: 100451

[2] US Food and Drug Administration. The FDA is Recommending Transition to Duodenoscopes with Innovative Designs to Enhance Safety:
FDA Safety communication. https://www.fda.gov/medical-devices/ safety-communications/fda-recommending-transition-duodenoscopes-innovative-designs-enhance-safety-fda-safety-communication

[3] Trindade AJ, Copland A, Bhatt A et al. Single-use duodenoscopes and duodenoscopes with disposable end caps. Gastrointest Endosc 2021; 93: 997-1005

[4] Napoléon B, Gonzalez JM, Grandval P et al. Evaluation of the performances of a single-use duodenoscope: Prospective multi-center national study. Dig Endosc 2021: doi:10.1111/den.13965

[5] Ross AS, Bruno MJ, Kozarek RA et al. Novel single-use duodenoscope compared with 3 models of reusable duodenoscopes for ERCP: a randomized bench-model comparison. Gastrointest Endosc 2020; 91: 396-403

[6] Muthusamy VR, Bruno M, Kozarek RA et al. Clinical evaluation of a single-use duodenoscope for endoscopic retrograde cholangiopancreatography. Clin Gastroenterol Hepatol 2020; 18: 2108-2117

[7] Bang JY, Hawes R, Varadarajulu S et al. Equivalent performance of single-use and reusable duodenoscopes in a randomised trial. Gut 2020: doi:10.1136/gutjnl-2020-321836

[8] Bang JY, Sutton B, Varadarajulu RS et al. Concept of disposable duodenoscope: at what cost? Gut 2019; 68: 1915-1917

[9] The duodenoscope design dilemma!Association for the Advancement of Medical Instrumentation. AAMI TIR30: A compendium of processes, materials, test methods, and acceptance criteria for cleaning reusable medical devices. Arlington: VA; 2011

[10] Bang JY, Rösch T, Kim HM et al. Prospective evaluation of an assessment tool for technical performance of duodenoscopes. Dig Endosc 2021; 33: 822-828 